\title{
Late Neogene history of the laurel tree (Laurus L., Lauraceae) based on phylogeographical analyses of Mediterranean and Macaronesian populations
}

\author{
Francisco Rodríguez-Sánchez ${ }^{1 \star}$, Beatriz Guzmán ${ }^{2}$, Alfredo Valido ${ }^{3}$,
} Pablo Vargas ${ }^{2}$ and Juan Arroyo ${ }^{1}$

\begin{abstract}
${ }^{1}$ Departamento de Biología Vegetal y Ecología, Universidad de Sevilla, Sevilla, ${ }^{2}$ Real Jardin Botánico, CSIC, Madrid and ${ }^{3}$ Área de Biodiversidad y Conservación, Universidad Rey Juan Carlos, Madrid and Integrative Ecology Group, Estación Biológica de Doñana, CSIC, Sevilla, Spain
\end{abstract}

\begin{abstract}
Aim The post-glacial range dynamics of many European plant species have been widely investigated, but information rapidly diminishes as one moves further back in time. Here we infer the historical range shifts of Laurus, a paradigmatic tree of the Tethyan flora that has covered southern Eurasia since the Oligo-Miocene, by means of phylogenetic and phylogeographical analyses.
\end{abstract}

Location Mediterranean Basin, Black Sea and Macaronesian archipelagos (Azores, Madeira, Canary Islands).

Methods We analysed plastid DNA (cpDNA) sequence (trnK-matK, trnD-trnT) variation in 57 populations of Laurus and three Lauraceae genera. Phylogenetic methods (maximum parsimony and Bayesian inference) and statistical parsimony networks were used to reconstruct relationships among haplotypes. These results were contrasted with the fossil record and bioclimatic niche-based model predictions of past distributions to infer the migration routes and location of refugia.

Results The phylogenetic tree revealed monophyly for Laurus. Overall sequence variability was low within Laurus, but six different haplotypes were distinguished and a single network retrieved, portraying three lineages primarily related to geography. A strongly divergent eastern lineage occupied Turkey and the Near East, a second clade was located in the Aegean region and, lastly, a western clade grouped all Macaronesian and central and western Mediterranean populations. A close relationship was observed between the Macaronesian populations of L. azorica and the western populations of $L$. nobilis.

Main conclusions The phylogeographical structure of Laurus preserves the imprints of an ancient contraction and break-up of the range that resulted in the evolution of separate cpDNA lineages in its western- and easternmost extremes. Intense range dynamics in the western Mediterranean and multiple glacial refugia contributed to the generation and long-term conservation of this phylogeographical pattern, as shown by the fit between the haplotype ranges and past suitable areas inferred from bioclimatic models. Finally, our results challenge the taxonomic separation of Laurus into two distinct species.

\section{Keywords}

Long-distance dispersal, Macaronesia, Mediterranean, Neogene, phylogeography, plastid sequences, range dynamics, refugia, relict, Tertiary. Universidad de Sevilla, Apdo. 1095, E-4108 Sevilla, Spain. E-mail: frodriguez@us.es 


\section{INTRODUCTION}

The history of the Mediterranean flora and vegetation has fascinated biogeographers ever since it was formally described as a floristic region (for a botanical account see Takhtajan, 1986). In particular, the prevalence of ancient subtropical taxa (e.g. Myrtus, Laurus, Olea, Phillyrea) in the Mediterranean flora has long been recognized. The ancestors of extant species of these genera occupied a wide region around the former Tethys Sea during most of the Palaeogene and early Neogene (Mai, 1989; Palamarev, 1989), when low and middle latitudes of the Northern Hemisphere were largely covered by broadleaved evergreen vegetation dominated by taxa of tropical affinities (e.g. Lauraceae, Myrtaceae, Palmae). This so-called 'Madrean-Tethyan' flora (Axelrod, 1975) suffered widespread range contractions and extinctions since the middle Miocene due to large-scale climatic and tectonic changes (Mai, 1989). In particular, the Tethys Sea was greatly reduced by the progressive proximity of the Eurasian and African plates, in conjunction with a cooler and drier climate (Krijgsman, 2002). The onset of the Mediterranean climate in the mid-Pliocene, as well as the increased aridity and cold temperatures brought about by Pleistocene glaciations, ultimately resulted in the extinction of most relict populations of Tethyan plants in southern Europe and North Africa (KovarEder et al., 2006).

The late Neogene range dynamics of those members of the former Tethyan flora that have survived to the present remain largely unknown. In contrast with increasingly available knowledge of the Quaternary range dynamics of temperate plant taxa (e.g. Hewitt, 2004), few studies have been conducted on species of Tethyan origin (Petit et al., 2005). Based on a comparison of fossil and extant floras from the Western Palaearctic, both Asia Minor and the Macaronesian Islands (Azores, Madeira and the Canaries) have traditionally been regarded as outstanding refugia for relict Tertiary lineages (Engler, 1879; Axelrod, 1975; Bramwell, 1976; Sunding, 1979; Cronk, 1992; Denk et al., 2001). Mesic areas within the Mediterranean Basin also enabled long-term survival of some species in pocket refugia (Thompson, 2005; Mejías et al., 2007). In the particular case of Macaronesia, close to the western end of the Mediterranean, recent phylogenetic studies have confirmed the existence of ancient (Tertiary) lineages, as well as close relationships with related Mediterranean taxa (Andrus et al., 2004; Carine et al., 2004; Vargas, 2007). Yet molecular studies have also shown that several presumed Macaronesian relict lineages have a recent, derived origin (reviewed by Emerson, 2002; Vargas, 2007). Thus, as different taxa usually show unrelated evolutionary patterns, generalizations are problematic. Moreover, most molecular studies of the Macaronesian flora have focused on phylogenetic (macroevolutionary) or within-archipelago phylogeographical patterns, and few have been undertaken at a population level encompassing both range-wide Mediterranean and Macaronesian areas (Comes, 2004). Thus, the migration dynamics responsible for those biogeographical patterns have rarely been explored.

The laurel tree (Laurus L.) is the only member of the Lauraceae that has persisted to the present in southern Eurasia, despite a considerable number of genera (Neolitsea, Lindera, Persea, Cinammomum and others) recorded in the MioPliocene (Mai, 1989; Barrón \& Peyrot, 2006). After considerable range reductions throughout the Neogene, its current distribution is limited to relatively mesic areas in the Mediterranean Basin, the Pontic region (southern Black Sea) and the Macaronesian archipelagos (Santos, 1990). Laurus is a dioecious tree with entomophilous pollination and fleshyfruited seeds dispersed by birds (Forfang \& Olesen, 1998; Hampe, 2003). Given its long-standing presence, Laurus represents an excellent model for exploring the evolutionary history of ancient Mediterranean-Macaronesian lineages. Indeed, several authors have emphasized the need for molecular studies involving extant Lauraceae in order to ascertain the biogeographical origin of the Macaronesian laurel forests (Emerson, 2002; Comes, 2004). Of the four genera of Lauraceae currently inhabiting Macaronesia, namely Apollonias, Ocotea, Persea and Laurus, the latter is the best suited with regard to testing Mediterranean-Macaronesian biogeographical connections, as it is the only one still persisting in the Mediterranean Basin.

Two species of Laurus have been traditionally recognized: Laurus nobilis L., distributed across the Mediterranean Basin and southern Black Sea, and Laurus azorica (Seub) Franco, endemic to Macaronesia and southern Morocco (Barbero et al., 1981; Jalas \& Suominen, 1991; Fig. 1). Key characters of the species, however, have been questioned in relation to morphological (Ferguson, 1974; Marques \& Sales, 1999) and genetic (Arroyo-García et al., 2001) data. Inference of genetic relatedness in the whole range of Laurus is needed to identify the level of evolutionary differentiation within the genus, past population dynamics, and the potential role of humanmediated introductions.

A previous study (Rodríguez-Sánchez \& Arroyo, 2008) based on bioclimatic niche modelling showed that Laurus experienced remarkable range retreat and fragmentation driven by climatic changes since the late Tertiary. The species may have persisted at small, isolated refugia in the Mediterranean Basin and Macaronesia during Pleistocene glaciations. Here we attempt to combine these three sources of information (fossil records, bioclimatic models and phylogeography) to infer the historical range dynamics and lineage evolution in Laurus through the late Neogene. Additionally, we discuss the taxonomic implications of our phylogenetic results for species delimitation within the genus Laurus.

\section{MATERIALS AND METHODS}

\section{Sampling strategy and DNA sequencing}

We sampled 57 populations throughout the natural range of Laurus (Fig. 1; for population data see Appendix S1). Fresh 


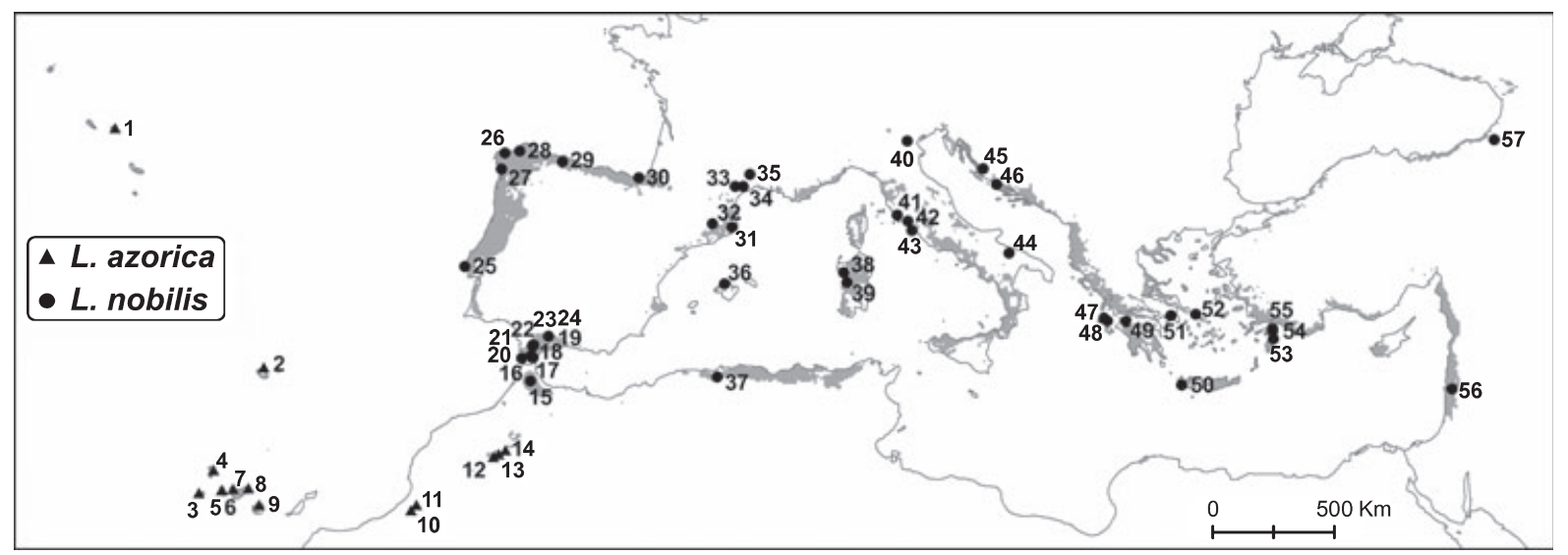

Figure 1 Map showing locations of Laurus populations sampled in this study. The current distribution of both species (L. nobilis and L. azorica) is shown in grey (after Rodríguez-Sánchez \& Arroyo, 2008).

leaves were collected and stored in silica gel until processing in the laboratory. Total genomic DNA was extracted using the Qiagen DNeasy Plant Mini Kit (Qiagen, Valencia, CA, USA).

We sequenced plastid DNA (cpDNA) to obtain haplotypes suitable for phylogeographical analyses. Assuming the standard maternal inheritance of plastids in angiosperms, any phylogeographical pattern should arise exclusively from successful seed-dispersal events. As we were concerned about previous findings of extremely low cpDNA variability in the Lauraceae (Rohwer, 2000; Chanderbali et al., 2001), we first performed a pilot study of sequence variability within Laurus at $11 \mathrm{cpDNA}$ regions (Appendix S2). Polymerase chain reaction (PCR) amplifications were performed on a Perkin-Elmer PCR System 9700 (Waltham, MA, USA) or an MJ Research thermal cycler. The PCR procedure included a denaturation step of 1-4 min at $94^{\circ} \mathrm{C}$, followed by $24-35$ cycles of $1 \mathrm{~min}$ at $94^{\circ} \mathrm{C}, 0.5-1 \mathrm{~min}$ at the annealing temperature of the respective DNA region (Appendix S2), and $1-2 \mathrm{~min}$ at $72^{\circ} \mathrm{C}$. One microlitre of dimethyl-sulfoxide (DMSO) was included in each $25 \mu \mathrm{L}$ reaction. Amplified products were cleaned using spin filter columns (PCR Clean-up kit; MoBio Laboratories, Carlsbad, CA, USA) following the manufacturer's protocols. Cleaned products were then directly sequenced by means of dye terminators (Big Dye Terminator ver. 2.0; Applied Biosystems, Little Chalfont, UK) following the manufacturer's protocols, and run into polyacrylamide electrophoresis gels (7\%) with an Applied Biosystems Prism model 3700 automated sequencer (Applied Biosystems, Foster City, CA, USA). PCR primers were used for cycle sequencing. We then assembled and edited the sequenced data using the program Seqed (Applied Biosystems). The limits of the regions were determined by the position of flanking primers. Finally, we selected the two spacers $(\operatorname{trn} K-m a t K, \operatorname{trn} D-\operatorname{trn} T)$ rendering a higher number of polymorphisms and extended the sequencing to one randomly chosen individual from each of the 57 sampled populations for both DNA regions. Given the low overall variability and the clear geographical segregation of the haplotypes found, we increased the population-sequencing effort only in those regions that contained more than one haplotype (eastern
Mediterranean, southern Iberia and northern Morocco; Fig. 1). In these regions, up to three individuals per population were sequenced. In total, we obtained sequences from 88 individuals of Laurus (for further information, including GenBank accession numbers, see Appendix S1). We also included one sample of Lindera benzoin Blume, a close relative of Laurus (Li et al., 2004), and two other Lauraceae species (Ocotea foetens Benth. \& Hook. and Persea indica Spreng) from the Canary Islands and Madeira, respectively, as outgroup accessions (GenBank codes FJ408866/67/68 and FJ408955/56/ 57). Sequences were aligned using ClustalW 1.83 (Chenna et al., 2003), with further adjustments by visual inspection.

\section{Phylogenetic and phylogeographical analyses}

Maximum parsimony (MP) and Bayesian inference (BI) analyses were performed on the combined trnK-matK/trnD$\operatorname{trn} T$ matrix. We conducted all parsimony analyses using Fitch parsimony (as implemented in PAUP*; Swofford, 1999) with equal weighting of all characters and of transitions/transversions. Heuristic searches were replicated 1000 times with random taxon addition sequences, tree bisection-reconnection (TBR) branch swapping, the options MulTrees and Steepest Descent in effect and holding 100 trees per replicate. We performed a full heuristic bootstrap analysis using 10,000 replicates with random taxon addition, TBR branch swapping, and the options Multrees and Steepest Descent in effect, and saving 10 trees per replicate.

In order to determine the simplest model of sequence evolution that best fits the sequence data, the Akaike information criterion was implemented in each data set using MrModeltest 1.1b (Posada \& Crandall, 1998; Nylander, 2002). A BI analysis was conducted in MrBAYEs $3.0 \mathrm{~b} 4$ (Ronquist \& Huelsenbeck, 2003) by means of two identical searches with three million generations each (four Markov chain Monte Carlo, chain temperature $=0.2$; sample frequency $=100$ ). In both runs, probabilities converged at the same stable value after approximately generation 45,000 . A $50 \%$ majority-rule consensus tree was calculated using the sumt command to yield the final 
Bayesian estimate of phylogeny. We used the posterior probability as an estimate of robustness.

Phylogeographical relationships of haplotypes were inferred by statistical parsimony (Posada \& Crandall, 2001) using TCS 1.21 (Clement et al., 2000). We ran separate analyses on the combined trnK-matK/trnD-trnT matrix with indels either coded as single-site substitutions or treated as missing characters. Length variations in mononucleotide repeats (Table 1) were kept for the analysis, as they provided a phylogeographically coherent signal without signs of homoplasy. Nonetheless, both haplotype networks had the same structure, differing only in the number of mutations connecting some haplotypes. Only the former network (with indels coded) is described for the sake of brevity.

\section{RESULTS}

The aligned length of the combined trnK-mat $K$ and trnD-trnT sequences was $2562 \mathrm{bp}$. Thirty-nine of the 66 total polymorphic sites were single-site substitutions, while mononucleotide repeats and insertions/deletions accounted for the remaining mutations (Table 1). Fourteen variable characters were parsimony-informative. The MP analysis generated two trees of 39 steps with a consistency index (CI) of 1.00 and a retention index (RI) of 1.00. The strict consensus tree (not shown) was identical to the BI tree using the simplest model of evolution (trnK-matK: KHY; trnD-trnT: GTR; Fig. 2), but displayed different support values. These phylogenetic analyses revealed the monophyly of Laurus and identified several clades within the genus, closely related to their geographical distribution (Fig. 2). However, L. nobilis appeared paraphyletic to L. azorica, the status of which remained equivocal.

Genetic variability within Laurus was remarkably low. However, six different cpDNA haplotypes, differing by up to nine mutations, were found. The phylogeographical analysis produced a single network of six extant Laurus haplotypes connected with no loops (Fig. 3a). This, together with high CI and RI values in the phylogenetic analysis, indicates no homoplasy signal of our molecular markers. All connections in the network were within the $95 \%$ parsimony limit, including those of Laurus haplotypes with the outgroup samples (L. benzoin, O. foetens, $P$. indica). There was a clear geographical structure of haplotypes (Fig. 3b; Appendix S1), and most haplotypes were confined to specific regions. However, one haplotype (H6) was widely distributed throughout the Mediterranean Basin, with the exception of the easternmost populations. Southern Iberia and the Aegean region were the only areas that contained more than one single haplotype (two and three, respectively), and even within these areas we found only one south-western Turkish (Marmaris Peninsula) population harbouring more than one haplotype (Fig. 3b).

The phylogeographical network (Fig. 3a) showed three different lineages primarily related to an east-west geographical gradient. All three lineages derived from an unsampled ancestor, which differed in only one mutation step from the extant Aegean Laurus populations (haplotype H1). A second lineage contained one remarkably divergent haplotype ( $\mathrm{H} 2$, separated by five mutations from the hypothetical ancestor haplotype) that was distributed from northern Turkey to Israel. The third lineage included all Macaronesian and western Mediterranean populations of L. nobilis and L. azorica. This western lineage comprised one central haplotype (H3), found in southern Morocco, Madeira and the Canary Islands, and three derived haplotypes observed in the Azores ( $\mathrm{H} 4)$, in southern Iberia (H5), and throughout much of the Mediterranean Basin from northern Morocco to the western Aegean Sea (H6).

\section{DISCUSSION}

We found low levels of cpDNA variation within Laurus at the 11 DNA regions tested (Appendix S2). Only two spacers (trnK-matK and $\operatorname{trn} D-t r n T)$ displayed a considerable number of nucleotide substitutions. Although low within-population variation might be the result of our limited sample, the same pattern was obtained across populations and geographical regions, and even between taxa. One might be surprised by this scarce genetic variation, considering the ancient origin and long evolutionary history of Laurus (Palamarev, 1989; see Appendix S3 for a compilation of Neogene fossil records of Laurus), which would have provided ample opportunities for lineage divergence. Nevertheless, low cpDNA variation has also been found in the Lauraceae as a whole (Rohwer, 2000; Chanderbali et al., 2001), and in other tree species of the Lauraceae ( $\mathrm{Wu}$ et al., 2006) and other families (e.g. Olea europaea, Besnard et al., 2007; Quercus suber, Magri et al., 2007; Pinus pinea, Vendramin et al., 2008; see also Shaw et al., 2005, for lineage comparison of these cpDNA regions across Spermatophyta). Reliable explanations for this low cpDNA variation include low mutation rates and long generation times, the demographic stability of most populations, or their relatively high gene flow (Petit et al., 2005; Petit \& Hampe, 2006; Smith \& Donoghue, 2008). In the particular case of Laurus, the phylogeographical pattern depicted here and the low level of DNA variation in the Lauraceae suggest that the limited haplotype diversity stems from historically low mutation rates. In addition, the dioecious character of Laurus should have increased the rate of cpDNA lineage sorting, as the effective population size is reduced relative to hermaphrodite species (Cruzan \& Templeton, 2000). A higher number of populations and haplotypes is needed to test the hypothesis of range expansion following demographic bottlenecks (Vendramin et al., 2008).

The six distinct haplotypes found showed a clear geographical structure across the range of Laurus, pointing to a limited influence of historical human-mediated translocations, despite the long history of cultivation. Three cpDNA lineages were detected (Fig. 3), one distributed around the Aegean Sea (hereafter termed the Aegean lineage), one across Asia Minor and the Near East (the eastern lineage), and the third through the western Mediterranean and Macaronesia (western lineage). All three lineages are derived from an unsampled - probably 


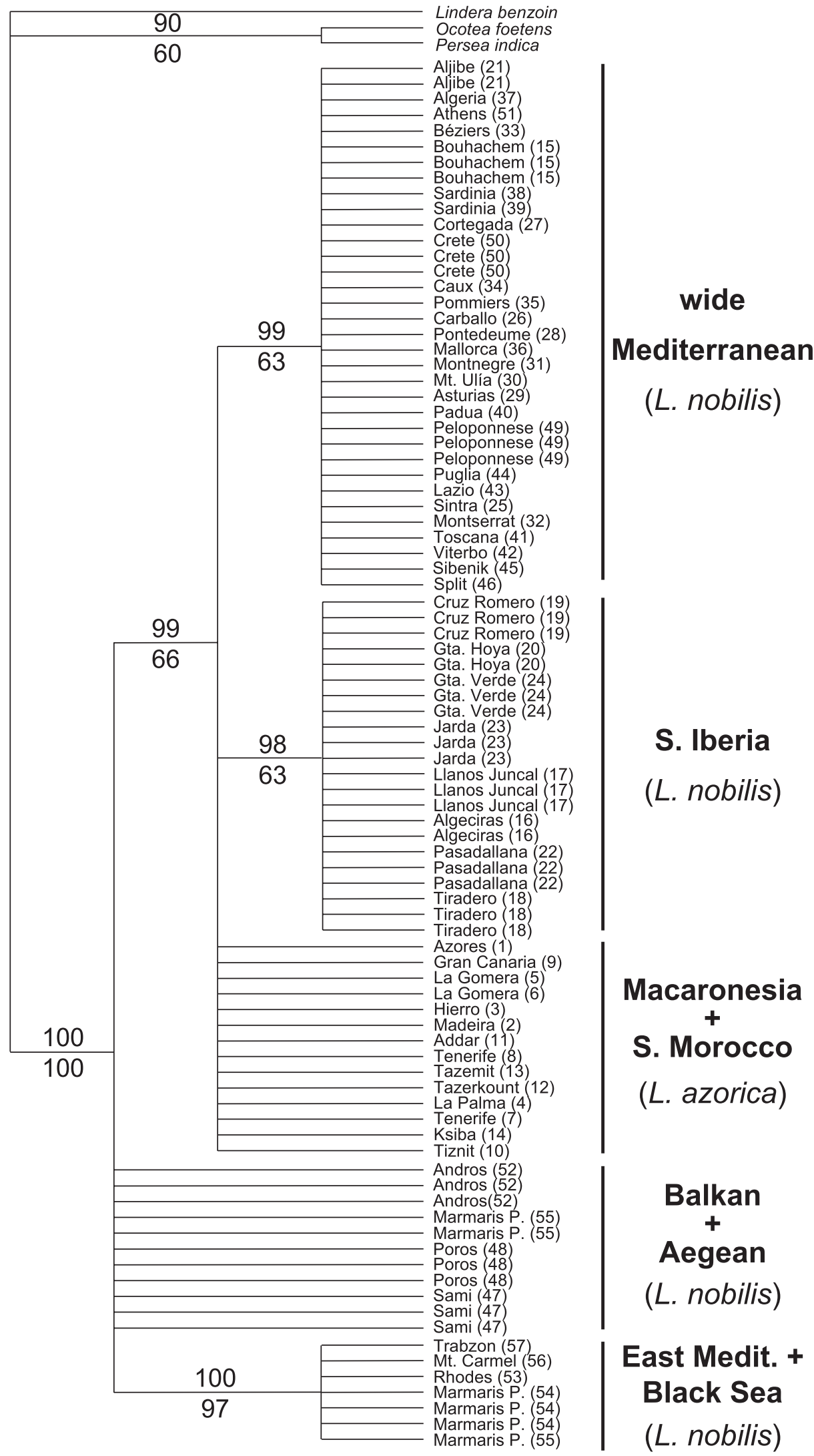

Figure 2 Consensus Bayesian inference tree based on the combined data sets of $\operatorname{trn} K-m a t K$ and $\operatorname{trnD}-\operatorname{trnT}$ sequences. Numbers above and below branches are Bayesian posterior probabilities and bootstrap values, respectively. Laurus population coding as in Fig. 1 and Appendix S1. 
(a)

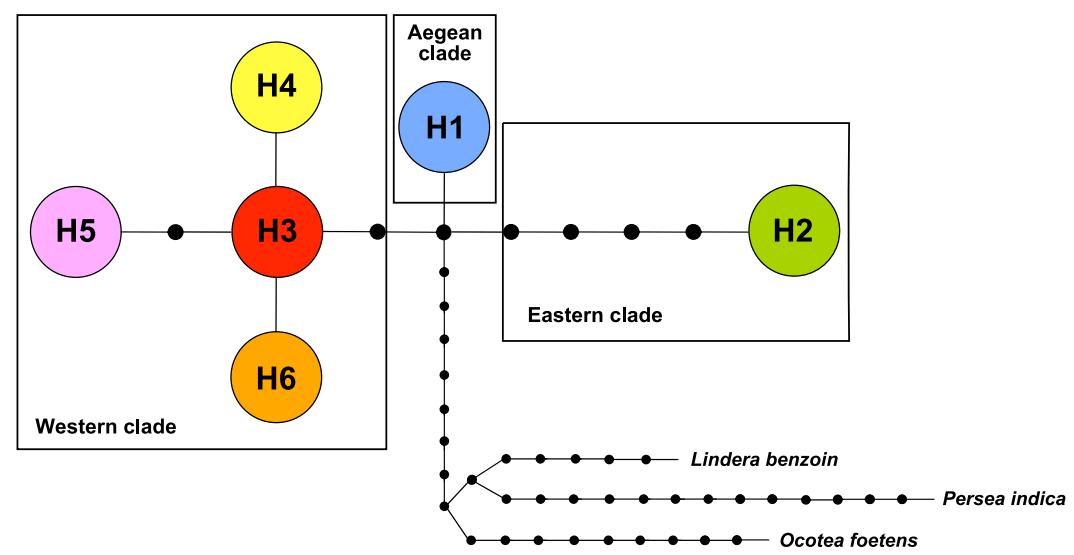

(b)

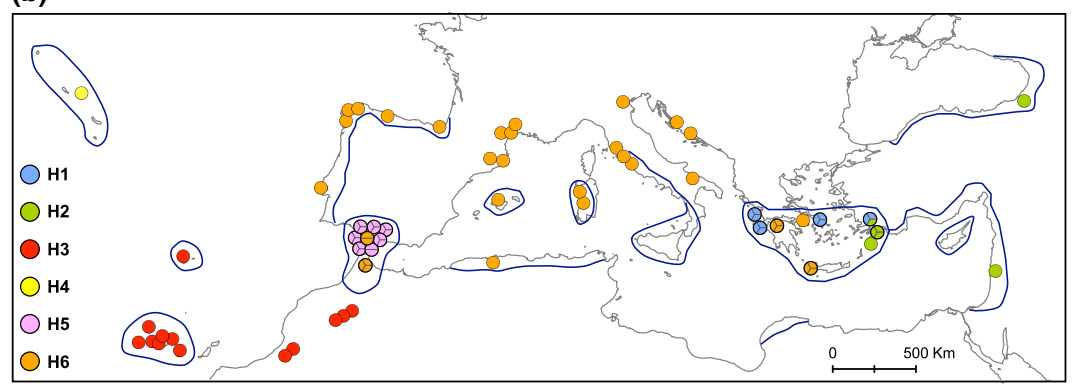

Figure 3 (a) Phylogeographical relationships among Laurus haplotypes, as inferred by statistical parsimony. Black circles indicate missing intermediate haplotypes. (b) Geographical distribution of Laurus plastid haplotypes. Sectors within circles represent number of individuals sampled and haplotypes found in each population. Dotted lines enclose main areas suitable for the persistence of Laurus populations during the last glacial period, as predicted by bioclimatic niche-based models (after Rodríguez-Sánchez \& Arroyo, 2008).

extinct - ancestor. The haplotype network suggests an eastern Mediterranean diversification of extant Laurus, followed by subsequent westward expansion by a single haplotype, which colonized and diversified across the western Mediterranean and Macaronesia. Such an east-west vicariance across the Mediterranean region has been described for several other plant (e.g. Lumaret et al., 2002, 2005; Hampe et al., 2003; Fady-Welterlen, 2005; Besnard et al., 2007) and animal taxa (e.g. Oosterbroek \& Arntzen, 1992), and has often been interpreted as the genetic footprint of old (pre-Quaternary) range dynamics coupled with changes in the Tethys-Mediterranean palaeogeography (Oosterbroek \& Arntzen, 1992; Petit et al., 2005). In particular, the continuous movement of microplates and the sporadic appearance of water barriers throughout the Neogene would favour both migration and differentiation within the Basin (Steininger \& Rögl, 1984; Rosenbaum et al., 2002). Few studies, however, have tested the temporal matching of significant palaeogeographical events with the divergence between lineages (through molecular dating; but cf. Comes \& Abbott, 2001; Oberprieler, 2005; Mansion et al., 2008). Despite the relatively abundant fossil record for Laurus since the early Miocene (Appendix S3), the lack of distinctive characters in their macrofossils unfortunately precludes calibration of a relaxed molecular clock that could inform on likely divergence dates for haplotypes
(Renner, 2005; Ho et al., 2008). Nonetheless, fossil records may help us to interpret the past range dynamics of Laurus through the Neogene, although the inherent limitations of such inferences should be recognized. First, the sampling effort in palaeobotanical studies is not homogeneous, and is clearly limited in some areas (e.g. Macaronesia, North Africa); thus, the lack of fossil evidence should not be equated with the absence of the species in that area. Moreover, the information on past distributions provided by the fossil record might be poorly correlated with the actual palaeodistribution of lowdensity species (McLachlan \& Clark, 2004). Lastly, extinctions followed by subsequent recolonization are difficult to infer from the fossil record. Unfortunately, in the particular case of Laurus, the poor state of conservation of most fossil records precludes the application of the cuticular analyses needed to confirm genus identification (Ferguson, 1974). Nevertheless, the abundant fossil evidence for other broadleaved evergreen species, including several genera of the Lauraceae, indicates the presence of extensive lauroid forests in the Mediterranean Basin - and probably also Macaronesia - throughout the Miocene and early Pliocene (Heer, 1857; Schmincke, 1968; Axelrod, 1975; Velitzelos \& Gregor, 1990; Barrón \& Peyrot, 2006; Kovar-Eder et al., 2006; Utescher et al., 2007).

In addition to fossil evidence, models that take into account the environmental requirements of species can alternatively be 
used to predict their potential distributions at different time stages (e.g. Cheddadi et al., 2006), providing independent evidence that may help to reduce the uncertainty associated with the fossil record. Rodríguez-Sánchez \& Arroyo (2008) used such a framework to reconstruct Laurus range dynamics over the past $3 \mathrm{Myr}$, documenting a process of range retreat and fragmentation driven by harsh climatic changes, but also outlining multiple isolated regions in the Mediterranean Basin and Macaronesia that could have acted as long-term refugia for the species. Interestingly, most of those regions (Macaronesian Islands, southern Iberia and North Africa, the Aegean and Black Seas, and the Near East; Fig. 3b) harbour distinct cpDNA haplotypes, supporting the notion that these regions have sustained populations long enough to allow their genetic divergence. It seems noteworthy in this context that most of the genetic distinctiveness of Laurus exists in those areas that are considered to be most vulnerable to predicted climate change (Rodríguez-Sánchez \& Arroyo, 2008). Considering the evidence as a whole (i.e. the low mutation rate of cpDNA, particularly slow in trees; the stability of climatic refugia in the Mediterranean region; and the sustained presence of Laurus fossil records throughout the Neogene, Appendix S3), together with some life-history characteristics of Laurus (long life span, remarkable sprouting ability and shade tolerance, bird-dispersed seeds) that confer high resilience to extinction (Bond \& Midgley, 2001), we hypothesize that the phylogeographical structure of Laurus might be of ancient origin. Further evidence, particularly that from the integration of phylogenetic dating and appropriate fossil records, is needed to provide accurate dates.

\section{Inferred range dynamics of Laurus across the Mediterranean and Macaronesia}

Despite the relative geographical proximity, the eastern lineage present in Turkey, Rhodes and the Near East is strongly differentiated from nearby Aegean populations by six changes in the cpDNA sequences. This sharp phylogeographical break across the Aegean has been found for other taxa (e.g. Nigella; Bittkau \& Comes, 2005) and roughly coincides with the well established floristic Rechinger's line (Strid, 1996). The existence of this barrier to plant migration and gene flow appears to stem from the palaeogeographical evolution of the region through the Miocene and early Pliocene (Greuter, 1979; see also Bittkau \& Comes, 2005, and references therein). Indeed, our phylogeographical reconstruction (Fig. 3a) agrees with an ancient split and posterior differentiation of the $\mathrm{H} 1$ and $\mathrm{H} 2$ lineages in the Balkan-Aegean and easternmost Mediterranean domains, respectively. In addition, historically low population sizes and limited seed dispersal across populations might have contributed to the maintenance of this phylogeographical break (Irwin, 2002). A fine-scaled sampling of populations across both regions, combined with appropriate molecular dating, should help to ascertain the role of those palaeogeographical changes on lineage divergence. We note, however, the presence of haplotypes of the two lineages in one single population from south-western Turkey (Fig. 3b), which points out that Rechinger's line may have been crossed in more recent times.

The western Mediterranean acted as a remarkable centre of diversification for Laurus, generating four of the six haplotypes detected. This pattern of greater differentiation in the west resembles that of other Mediterranean taxa of ancient origin, such as Frangula alnus (Hampe et al., 2003), Hedera (Valcárcel et al., 2003) and Olea europaea (Besnard et al., 2007). The ancestral haplotype (H3) for this western clade of Laurus is currently present in Madeira, the Canary Islands and southern Morocco, the other three western haplotypes (those of the Azores, southern Iberia and the widely distributed Mediterranean haplotype H6) deriving from it. Colonization of the western Mediterranean Basin by Laurus might have occurred as early as the middle Miocene, as suggested by fossil evidence in north-east Iberia, although subsequent recolonizations cannot be discounted. Similarly, southern Iberian populations of Laurus (haplotype H5) may already have been established in the Pliocene, considering the occurrence of fossil records of Laurophyllum (probably attributable to Laurus) from that period in nearby areas (Barrón et al., 2003) and the long-term environmental suitability of this region for Laurus persistence (Rodríguez-Sánchez \& Arroyo, 2008; Rodríguez-Sánchez et al., 2008).

The current geographical pattern of haplotypes suggests a complex history of range fragmentation and retreat, coupled with certain long-distance dispersal events. The latter are necessary to explain at least the presence of Laurus in the Macaronesian archipelagos. Laurus seeds are dispersed by medium- to large-sized birds (Hampe, 2003; F.R.S., unpublished data), and are therefore capable of long-distance dispersal to oceanic islands. Recent long-distance dispersal, probably favoured by human translocations, might also explain the wide distribution of the H6 haplotype across the Mediterranean. This haplotype should have experienced the most intense range shifts as driven by the Quaternary glacial cycles, although several glacial refugia have been proposed based on their climatic suitability (Rodríguez-Sánchez \& Arroyo, 2008). In agreement with this, the amplified fragment length polymorphism (AFLP) study by Arroyo-García et al. (2001) detected some degree of genetic differentiation among populations fixed for our H6 haplotype, which suggests the persistence of Laurus populations at multiple isolated refugia (e.g. Cantabrian Range, southern and north-east Iberia, Sardinia, Italian peninsula) during the glacial periods. Nonetheless, some extant populations may result from recent colonizations, such as those in south-east France, which appear more related to Italian Laurus populations than to nearby populations from north-east Iberia (Arroyo-García et al., 2001).

The ancestral position of the Moroccan-Macaronesian haplotype $\mathrm{H} 3$ in the western clade, although somewhat anticipated by Bramwell (1972), is remarkable (see also Carine et al., 2004). Further evidence from chromosome counts in both species $(2 n=24,48$ in L. nobilis, and $2 n=36,48$ in 
L. azorica; Ehrendorfer et al., 1968; Jalas \& Suominen, 1991) suggests a derived polyploid origin for western Laurus populations. If the multiple descriptions of L. azorica from Neogene deposits in western Europe (Barbero et al., 1981) are considered to be reliable, the current distribution of this haplotype (H3) would imply an extraordinary range retreat towards southern locations, followed by extinction in northern countries and colonization of Madeira and the Canaries. Alternatively, North Africa might have been colonized early by an extinct ancestor, and from there a formidable range expansion of the species could have occurred towards Macaronesia, Iberia and the entire western Mediterranean. A similar colonization pattern was found in Quercus ilex (Lumaret et al., 2002), yet the species apparently did not reach Macaronesia (but see de Nascimento et al., 2009). In fact, the former tropical climate of North Africa enabled the presence of extensive lauroid forests throughout much of the Miocene (Axelrod, 1975).

Unfortunately, the spatial and temporal realms of the colonization of Macaronesia from Laurus continental populations cannot be fully inferred with the available evidence. Whereas our population sample from the Macaronesian islands is relatively exhaustive, the lack of haplotype variability and reliable fossil records on the islands preclude any plausible reconstruction. Arroyo-García et al. (2001) used a more appropriate marker set (AFLP) at this scale, but their sampling included very few Macaronesian populations and none from Morocco. Thus, colonization events to and within Macaronesia could not be clearly inferred. However, results from this AFLP study suggested recent introductions into Madeira and the Canary Islands from Iberian populations (Arroyo-García et al., 2001). Given the distribution of extant cpDNA haplotypes found here, North Africa emerges as the most likely source (see also Axelrod, 1975). Although neither process excludes the other, a North African-Canarian connection has been found in many other plant and animal taxa (Hess et al., 2000; Carranza et al., 2002; Valcárcel et al., 2003; Juste et al., 2004; Guzmán \& Vargas, 2005; Besnard et al., 2007; see also Médail \& Quézel, 1999).

\section{How many species within Laurus?}

Our results correspond with those of Arroyo-García et al. (2001) in that they do not support the current delimitation of species within the genus Laurus. Both genetic analyses show that western Mediterranean and particularly Iberian laurel populations (considered as ' $L$. nobilis') are more closely related to Macaronesian ' $L$. azorica' than to other ' $L$. nobilis' populations from the eastern Mediterranean. Analyses of morphological characters (Ferguson, 1974; Marques \& Sales, 1999) point in the same direction. No reliable taxonomic key characters have been proposed, considering the remarkable leaf plasticity (Franco, 1960; see also Giacomini \& Zaniboni, 1946). Moreover, both species are interfertile and their hybrid progeny grows well (Todua, 1988). Given all this evidence, we argue that the current taxonomic status of Laurus species requires a critical re- evaluation based on solid criteria. For instance, the recent classification of Madeiran, Canarian and southern Moroccan populations of Laurus as a third species, L. novocanariensis (Rivas-Martínez et al., 2002), appears to be wanting with regard to morphological and molecular data (Franco, 1960; Marques \& Sales, 1999; Arroyo-García et al., 2001). Although there is a need for further studies, including detailed morphological analyses and more genetic markers, the current evidence appears to support the existence of only one species of Laurus.

We are now beginning to understand the range dynamics of European plants since the Last Glacial Maximum (c. $21 \mathrm{ka}$ ), but information diminishes rapidly as one moves further back in time, and to lower latitudes. Studies that apply integrative approaches to suitable model organisms are needed in order to reveal the more complex and much older range dynamics experienced by plants in the Mediterranean Basin and Macaronesia (Petit et al., 2005; Vargas, 2007). Here we have shown that phylogeographical patterns are better explained when independent evidence from other fields is brought to bear, such as the fossil record or bioclimatic modelling. These joint analyses will ultimately throw light on one of the most recurrent questions in historical biogeography, the origin of the Mediterranean flora and vegetation.

\section{ACKNOWLEDGEMENTS}

We are very grateful to E. Cano for his keen laboratory assistance and to R. Santos for her kind help with sequence alignment. J. A. Rosselló and R. G. Albaladejo provided useful insights at the initial stages of this study, and G. Brea helped with the figures. This range-wide study could not have been done without the generous collaboration of colleagues who provided samples and information on Laurus from disparate regions: L. Navarro (Azores, Galicia), A. Marrero (Canary Islands), I. Rodríguez (Basque Country), X. Picó and F. Ojeda (Catalonia), S. Lavergne (France), A. Holguín (Cádiz), H. Sáinz-Ollero (Morocco), H. Himrane (Algeria), A. Traveset and J. M. González (Mallorca), P. Politi and K. Psathakis (Greece), S. Pisanu (Sardinia), G. Filibeck, I. Tursi and Claudia Poggi (Italy), A. Dafni (Israel) and F. Tilki (Turkey). We also wish to express our gratitude to A. Hampe, P. Jordano and M. B. García for their helpful comments and the thorough revision of earlier versions of the manuscript. E. Barrón, T. Utescher and J. S. Carrión kindly sent reprints and helped with the palaeobotanical data, while D. Posada provided valuable comments for the interpretation of phylogeographical relationships. Insightful comments from D. Magri and two anonymous referees greatly contributed to improving the final manuscript. Financial support was provided by research contracts with GIASA and partially by MEC grants (BOS200307924-CO2-01, CGL2006-13847-CO2-01). A.V. benefited from a postdoctoral scholarship from the Consejería de Innovación, Ciencia y Empresa (Innovation, Science and Business Department) of the Junta de Andalucía (Andalucía Regional Government), and F.R.S. was supported by a predoctoral FPU studentship from MEC. 


\section{REFERENCES}

Andrus, N., Trusty, J., Santos-Guerra, A., Jansen, R.K. \& Francisco-Ortega, J. (2004) Using molecular phylogenies to test phytogeographical links between East/South AfricaSouthern Arabia and the Macaronesian islands - a review, and the case of Vierea and Pulicaria section Vieraeopsis (Asteraceae). Taxon, 53, 333-346.

Arroyo-García, R., Martínez-Zapater, J.M., Fernández Prieto, J.A. \& Álvarez-Arbesu, R. (2001) AFLP evaluation of genetic similarity among laurel populations (Laurus L.). Euphytica, 122, 155-164.

Axelrod, D.I. (1975) Evolution and biogeography of MadreanTethyan sclerophyll vegetation. Annals of the Missouri Botanical Garden, 62, 280-334.

Barbero, M., Benabid, A., Peyre, C. \& Quézel, P. (1981) Sur la presence au Maroc de Laurus azorica (Seub.) Franco. Anales del Jardín Botánico de Madrid, 37, 467-472.

Barrón, E. \& Peyrot, D. (2006) La vegetación forestal en el Terciario. Paleoambientes y cambio climático (ed. by J.S. Carrión, S. Fernández and N. Fuentes), pp. 55-76. Fundación Séneca - Agencia de Ciencia y Tecnología de la Región de Murcia, Murcia, Spain.

Barrón, E., Muñiz, F. \& Mayoral, E. (2003) Aspectos macroflorísticos del Plioceno de Lepe (Cuenca del Guadalquivir, Huelva, España). Consideraciones paleoecológicas. Boletín de la Real Sociedad Española de Historia Natural Sección Geológica, 98, 91-109.

Besnard, G., Rubio de Casas, R. \& Vargas, P. (2007) Plastid and nuclear DNA polymorphism reveals historical processes of isolation and reticulation in the olive tree complex (Olea europaea). Journal of Biogeography, 34, 736-752.

Bittkau, C. \& Comes, H.P. (2005) Evolutionary processes in a continental island system: molecular phylogeography of the Aegean Nigella arvensis alliance (Ranunculaceae) inferred from chloroplast DNA. Molecular Ecology, 14, 4065-4083.

Bond, W.J. \& Midgley, J.J. (2001) Ecology of sprouting in woody plants: the persistence niche. Trends in Ecology and Evolution, 16, 45-51.

Bramwell, D. (1972) Endemism in the flora of the Canary Islands. Taxonomy, phytogeography and evolution (ed. by D.H. Valentine), pp. 141-159. Academic Press, London.

Bramwell, D. (1976) The endemic flora of the Canary Islands: distribution, relationships and phytogeography. Biogeography and ecology in the Canary Islands (ed. by G. Kunkel), pp. 207-240. Dr W. Junk, The Hague.

Carine, M.A., Russell, S.J., Santos-Guerra, A. \& FranciscoOrtega, J. (2004) Relationships of the Macaronesian and Mediterranean floras: molecular evidence for multiple colonizations into Macaronesia and back-colonization of the continent in Convolvulus (Convolvulaceae). American Journal of Botany, 91, 1070-1085.

Carranza, S., Arnold, E.N., Mateo, J.A. \& Geniez, P. (2002) Relationships and evolution of the North African geckos, Geckonia and Tarentola (Reptilia: Gekkonidae), based on mitochondrial and nuclear DNA sequences. Molecular Phylogenetics and Evolution, 23, 244-256.

Chanderbali, A.S., Van der Werff, H. \& Renner, S.S. (2001) Phylogeny and historical biogeography of Lauraceae: evidence from the chloroplast and nuclear genomes. Annals of the Missouri Botanical Garden, 88, 104-134.

Cheddadi, R., Vendramin, G.G., Litt, T., François, L., Kageyama, M., Lorentz, S., Laurent, J.M., de Beaulieu, J.L., Sadori, L., Jost, A. \& Lunt, D. (2006) Imprints of glacial refugia in the modern genetic diversity of Pinus sylvestris. Global Ecology and Biogeography, 15, 271-282.

Chenna, R., Sugawara, H., Koike, T., Lopez, R., Gibson, T.J., Higgins, D.G. \& Thompson, J.D. (2003) Multiple sequence alignment with the Clustal series of programs. Nucleic Acids Research, 31, 3497-3500.

Clement, M., Posada, D. \& Crandall, K.A. (2000) TCS: a computer program to estimate gene genealogies. Molecular Ecology, 9, 1657-1659.

Comes, H.P. (2004) The Mediterranean region - a hotspot for plant biogeographic research. New Phytologist, 164, 11-14.

Comes, H.P. \& Abbott, R.J. (2001) Molecular phylogeography, reticulation, and lineage sorting in Mediterranean Senecio sect. Senecio (Asteraceae). Evolution, 55, 1943-1962.

Cronk, Q.C.B. (1992) Relict floras of Atlantic islands: patterns assessed. Biological Journal of the Linnean Society, 46, 91-103.

Cruzan, M.B. \& Templeton, A.R. (2000) Paleoecology and coalescence: phylogeographic analysis of hypotheses from the fossil record. Trends in Ecology and Evolution, 15, 491-496.

Denk, T., Frotzler, N. \& Davitashvili, N. (2001) Vegetational patterns and distribution of relict taxa in humid temperate forests and wetlands of Georgia (Transcaucasia). Biological Journal of the Linnean Society, 72, 287-332.

Ehrendorfer, F., Krendl, F., Habeler, E. \& Sauer, W. (1968) Chromosome numbers and evolution in primitive angiosperms. Taxon, 17, 337-353.

Emerson, B.C. (2002) Evolution on oceanic islands: molecular phylogenetic approaches to understanding pattern and process. Molecular Ecology, 11, 951-966.

Engler, A. (1879) Versuch einer Entwickllungsgeschichte, insbesondere der Florengebiete seit der Tertiärperiode. I. Die extratropischen Gebiete der nördlichen Hemisphäre. W. Engelmann, Leipzig, Germany.

Fady-Welterlen, B. (2005) Is there really more biodiversity in Mediterranean forest ecosystems? Taxon, 54, 905-910.

Ferguson, D.K. (1974) On the taxonomy of recent and fossil species of Laurus (Lauraceae). Botanical Journal of the Linnean Society, 68, 51-72.

Forfang, A.S. \& Olesen, J.M. (1998) Male-biased sex ratio and promiscuous pollination in the dioecious island tree Laurus azorica (Lauraceae). Plant Systematics and Evolution, 212, 143-157.

Franco, J.A. (1960) Lauráceas Macaronésicas. Anais do Instituto Superior de Agronomia de Lisboa, 23, 89-104.

Giacomini, V. \& Zaniboni, A. (1946) Osservazioni sulla variabilità del 'Laurus nobilis L.' nel bacino del Lago di Garda. Archivio Botanico, 22, 1-16. 
Greuter, W. (1979) The origins and evolution of island floras as exemplified by the Aegean archipelago. Plants and islands (ed. by D. Bramwell), pp. 87-106. Academic Press, London. Guzmán, B. \& Vargas, P. (2005) Systematics, character evolution, and biogeography of Cistus L. (Cistaceae) based on ITS, trnL-trnF, and matK sequences. Molecular Phylogenetics and Evolution, 37, 644-660.

Hampe, A. (2003) Frugivory in European laurel: how extinct seed dispersers have been substituted. Bird Study, 50, 280-284.

Hampe, A., Arroyo, J., Jordano, P. \& Petit, R.J. (2003) Rangewide phylogeography of a bird-dispersed Eurasian shrub: contrasting Mediterranean and temperate glacial refugia. Molecular Ecology, 12, 3415-3426.

Heer, O. (1857) Über die fossilen pflanzen von St. Jorge in Madeira. Neue Denkschriften der Allgemeinen schweizerischen Gesellschaft für die gessamten Naturwissenschaften, 5.

Hess, J., Kadereit, J.W. \& Vargas, P. (2000) The colonization history of Olea europaea L. in Macaronesia based on internal transcribed spacer 1 (ITS-1) sequences, randomly amplified polymorphic DNAs (RAPD), and intersimple sequence repeats (ISSR). Molecular Ecology, 9, 857-868.

Hewitt, G.M. (2004) Genetic consequences of climatic oscillations in the Quaternary. Philosophical Transactions of the Royal Society B: Biological Sciences, 359, 183-195.

Ho, S.Y.W., Saarma, U., Barnett, R., Haile, J. \& Shapiro, B. (2008) The effect of inappropriate calibration: three case studies in molecular ecology. PLoS ONE, 3, e1615 (doi: 10.1371/journal.pone.0001615).

Irwin, D.E. (2002) Phylogeographic breaks without geographic barriers to gene flow. Evolution, 56, 2383-2394.

Jalas, J. \& Suominen, J. (1991) Atlas Florae Europaeae (Paeoniaceae to Capparaceae). Helsinki University Printing House, Helsinki, Finland.

Juste, J., Ibáñez, C., Muñoz, J., Trujillo, D., Benda, P., Karatas, A. \& Ruedi, M. (2004) Mitochondrial phylogeography of the long-eared bats (Plecotus) in the Mediterranean Palaearctic and Atlantic Islands. Molecular Phylogenetics and Evolution, 31, 1114-1126.

Kovar-Eder, J., Kvaček, Z., Martinetto, E. \& Roiron, P. (2006) Late Miocene to Early Pliocene vegetation of southern Europe (7-4 Ma) as reflected in the megafossil plant record. Palaeogeography, Palaeoclimatology, Palaeoecology, 238, 321-339.

Krijgsman, W. (2002) The Mediterranean: Mare Nostrum of Earth sciences. Earth and Planetary Science Letters, 205, 1-12.

Li, J., Christophel, D.C., Conran, J.G. \& Li, H.W. (2004) Phylogenetic relationships within the 'core' Laureae (Litsea complex, Lauraceae) inferred from sequences of the chloroplast gene matK and nuclear ribosomal DNA ITS regions. Plant Systematics and Evolution, 246, 19-34.

Lumaret, R., Mir, C., Michaud, H. \& Raynal, V. (2002) Phylogeographical variation of chloroplast DNA in holm oak (Quercus ilex L.). Molecular Ecology, 11, 2327-2336.

Lumaret, R., Tryphon-Dionnet, M., Michaud, H., Sanuy, A., Ipotesi, E., Born, C. \& Mir, C. (2005) Phylogeographical variation of chloroplast DNA in cork oak (Quercus suber). Annals of Botany, 96, 853-861.
Magri, D., Fineschi, S., Bellarosa, R., Buonamici, A., Sebastiani, F., Schirone, B., Simeone, M.C. \& Vendramin, G.G. (2007) The distribution of Quercus suber chloroplast haplotypes matches the palaeogeographical history of the western Mediterranean. Molecular Ecology, 16, 5259-5266.

Mai, D.H. (1989) Development and regional differentiation of the European vegetation during the Tertiary. Plant Systematics and Evolution, 162, 79-91.

Mansion, G., Rosenbaum, G., Schoenenberger, N., Bacchetta, G., Rosselló, J.A. \& Conti, E. (2008) Phylogenetic analysis informed by geological history supports multiple, sequential invasions of the Mediterranean Basin by the angiosperm family Araceae. Systematic Biology, 57, 269-285.

Marques, A.R. \& Sales, F. (1999) Laurus L., um elemento arcaico na flora da Macaronesia. V Jornadas de Taxonomia Botânica, Lisboa.

McLachlan, J.S. \& Clark, J.S. (2004) Reconstructing historical ranges with fossil data at continental scales. Forest Ecology and Management, 197, 139-147.

Médail, F. \& Quézel, P. (1999) The phytogeographical significance of SW Morocco compared to the Canary Islands. Plant Ecology, 140, 221-244.

Mejías, J.A., Arroyo, J. \& Marañón, T. (2007) Ecology and biogeography of plant communities associated with the post PlioPleistocene relict Rhododendron ponticum subsp. baeticum in southern Spain. Journal of Biogeography, 34, 456-472.

de Nascimento, L., Willis, K.J., Fernández-Palacios, J.M., Criado, C. \& Whittaker, R.J. (2009) The long-term ecology of the lost forests of La Laguna, Tenerife (Canary Islands). Journal of Biogeography, 36, 499-514.

Nylander, J.A.A. (2002) MrModeltest, version 1.1b. Department of Systematic Zoology, Uppsala University, Sweden.

Oberprieler, C. (2005) Temporal and spatial diversification of Circum-Mediterranean Compositae-Anthemideae. Taxon, 54, 951-966.

Oosterbroek, P. \& Arntzen, J.W. (1992) Area-cladograms of circum-Mediterranean taxa in relation to Mediterranean palaeogeography. Journal of Biogeography, 19, 3-20.

Palamarev, E. (1989) Paleobotanical evidences of the Tertiary history and origin of the Mediterranean sclerophyll dendroflora. Plant Systematics and Evolution, 162, 93-107.

Petit, R.J. \& Hampe, A. (2006) Some evolutionary consequences of being a tree. Annual Review of Ecology, Evolution, and Systematics, 37, 187-214.

Petit, R.J., Hampe, A. \& Cheddadi, R. (2005) Climate changes and tree phylogeography in the Mediterranean. Taxon, 54, 877-885.

Posada, D. \& Crandall, K.A. (1998) MODELTEST: testing the model of DNA substitution. Bioinformatics, 14, 817-818.

Posada, D. \& Crandall, K.A. (2001) Intraspecific gene genealogies: trees grafting into networks. Trends in Ecology and Evolution, 16, 37-45.

Renner, S.S. (2005) Relaxed molecular clocks for dating historical plant dispersal events. Trends in Plant Science, 10, 550-558.

Rivas-Martínez, S., Díaz, T.E., Fernández-González, F., Izco, J., Loidi, J., Lousã, M. \& Penas, A. (2002) Vascular plant com- 
munities of Spain and Portugal: addenda to the syntaxonomical checklist of 2001. Itinera Geobotanica, 15, 5-922.

Rodríguez-Sánchez, F. \& Arroyo, J. (2008) Reconstructing the demise of Tethyan plants: climate-driven range dynamics of Laurus since the Pliocene. Global Ecology and Biogeography, 17, 685-695.

Rodríguez-Sánchez, F., Pérez-Barrales, R., Ojeda, F., Vargas, P. \& Arroyo, J. (2008) The Strait of Gibraltar as a melting pot for plant biodiversity. Quaternary Science Reviews, 27, 21002117.

Rohwer, J.G. (2000) Toward a phylogenetic classification of the Lauraceae: evidence from matK sequences. Systematic Botany, 25, 60-71.

Ronquist, F. \& Huelsenbeck, J.P. (2003) MrBayes 3: Bayesian phylogenetic inference under mixed models. Bioinformatics, 19, 1572-1574.

Rosenbaum, G., Lister, G.S. \& Duboz, C. (2002) Reconstruction of the tectonic evolution of the western Mediterranean since the Oligocene. Journal of the Virtual Explorer, 8, 107-126.

Santos, A. (1990) Evergreen forests in the Macaronesian region. Council of Europe, Strasbourg, France.

Schmincke, H.-U. (1968) Pliozäne, subtropische vegetation auf Gran Canaria. Naturwissenschaften, 55, 185-186.

Shaw, J., Lickey, E., Beck, J., Farmer, S., Liu, W., Miller, J., Siripun, K., Winder, C., Schilling, E. \& Small, R. (2005) The tortoise and the hare II: relative utility of 21 noncoding chloroplast DNA sequences for phylogenetic analysis. American Journal of Botany, 92, 142-166.

Smith, S.A. \& Donoghue, M.J. (2008) Rates of molecular evolution are linked to life history in flowering plants. Science, 322, 86-89.

Steininger, F.F. \& Rögl, F. (1984) Palaeogeography and palinspatic reconstruction of the Neogene of the Mediterranean and Paratethys. The geological evolution of the Eastern Mediterranean (ed. by J.E. Dixon and A.H.F. Robertson), pp. 659-668. Geological Society Special Publication No. 17. Blackwell Scientific, Oxford.

Strid, A. (1996) Phytogeographia Aegaea and the Flora Hellenica database. Annalen des Naturhistorischen Museums in Wien, 98B(Suppl.), 279-289.

Sunding, P. (1979) Origins of the Macaronesian flora. Plants and islands (ed. by D. Bramwell), pp. 13-40. Academic Press, London.

Swofford, D.L. (1999) PAUP*: phylogenetic analysis using parsimony, version 4.0. Illinois Natural History Survey, Champaign, IL.

Takhtajan, A. (1986) Floristic regions of the world. University of California Press, Berkeley, CA, USA.

Thompson, J.D. (2005) Plant evolution in the Mediterranean. Oxford University Press, Oxford.

Todua, B.T. (1988) Karyology of laurel species and forms. Biology bulletin of the Academy of Sciences of the USSR, 14, 292-299.

Utescher, T., Erdei, B., Fronçois, L. \& Mosbrugger, V. (2007) Tree diversity in the Miocene Forests of Western Eurasia. Palaeogeography, Palaeoclimatology, Palaeoecology, 253, 226-250.
Valcárcel, V., Fiz, O. \& Vargas, P. (2003) Chloroplast and nuclear evidence for multiple origins of polyploids and diploids of Hedera (Araliaceae) in the Mediterranean Basin. Molecular Phylogenetics and Evolution, 27, 1-20.

Vargas, P. (2007) Are Macaronesian islands refugia of relict plant lineages?: a molecular survey. Phylogeography in Southern European refugia: evolutionary perspectives on the origins and conservation of European biodiversity (ed. by S.J. Weiss and N. Ferrand), pp. 297-314. Springer, Berlin.

Velitzelos, E. \& Gregor, H.-J. (1990) Some aspects of the Neogene floral history in Greece. Review of Palaeobotany and Palynology, 62, 291-307.

Vendramin, G.G., Fady, B., González-Martínez, S.C., Hu, F.S., Scotti, I., Sebastiani, F., Soto, A. \& Petit, R.J. (2008) Genetically depauperate but widespread: the case of an emblematic Mediterranean pine. Evolution, 62, 680-688.

Wu, S.-H., Hwang, C.-Y., Lin, T.-P., Chung, J.-D., Cheng, Y.-P. \& Hwang, S.-Y. (2006) Contrasting phylogeographical patterns of two closely related species, Machilus thunbergii and Machilus kusanoi (Lauraceae), in Taiwan. Journal of Biogeography, 33, 936-947.

\section{SUPPORTING INFORMATION}

Additional Supporting Information is available for this article:

Appendix S1 Data on sampled Laurus populations: locality, species assignation, number of samples included (with their corres ponding GenBank accession numbers) and haplotypes found. Appendix S2 Plastid DNA regions sampled and primers used for the study of sequence variability in Laurus.

Appendix S3 Map of Neogene fossil records of Laurus and source references.

Please note: Wiley-Blackwell is not responsible for the content or functionality of any supporting materials supplied by the authors. Any queries (other than missing material) should be directed to the corresponding author of the article.

\section{BIOSKETCH}

Francisco Rodríguez-Sánchez is a postgraduate student at the Department of Plant Biology and Ecology, University of Seville. He is currently completing his $\mathrm{PhD}$ on the biogeography and ecology of relict trees in the Mediterranean. The authors of this paper constitute an interdisciplinary team of molecular and field biologists primarily interested in the ecology, evolution and biogeography of Mediterranean and Macaronesian plants.

Editor: Malte Ebach

This paper stems from a contribution initially presented at the conference Origin and Evolution of Biota in Mediterranean Climate Zones: an Integrative Vision, held in Zurich on 14-15 July 2007. 
Appendix S1 Additional information on the Laurus populations sampled in this study: population code, locality, species assignation, geographical coordinates, number of samples included in the molecular analyses, haplotypes found in each population and GenBank accession numbers.

\begin{tabular}{|c|c|c|c|c|c|c|c|c|c|}
\hline No. & Country & Locality & Species & $\begin{array}{c}\text { Latitude } \\
\left({ }^{\circ} \mathrm{N}\right)\end{array}$ & $\begin{array}{c}\text { Longitude } \\
\left({ }^{\circ} \mathrm{E}\right)^{*}\end{array}$ & $\begin{array}{c}\text { No. of } \\
\text { samples }\end{array}$ & Haplotype & $\begin{array}{c}\operatorname{trn} \mathrm{D}-\operatorname{trn} \mathrm{T} \\
\text { accession no. }\end{array}$ & $\begin{array}{c}\text { trnK-matK } \\
\text { accession no. }\end{array}$ \\
\hline 1 & Portugal & Terceira (Azores) & L. azorica & 38.7500 & -27.2100 & 1 & $\mathrm{H} 4$ & FJ408965 & FJ408876 \\
\hline 2 & Portugal & Madeira & L. azorica & 32.7768 & -16.9963 & 1 & $\mathrm{H} 3$ & FJ409002 & FJ408913 \\
\hline 3 & Spain & Mencafete, El Hierro (Canary I.) & L. azorica & 27.7424 & -18.1006 & 1 & $\mathrm{H} 3$ & FJ408994 & FJ408905 \\
\hline 4 & Spain & Barranco Seco, La Palma (Canary I.) & L. azorica & 28.7418 & -17.7860 & 1 & H3 & FJ409035 & FJ408946 \\
\hline 5 & Spain & Acebiños, La Gomera (Canary I.) & L. azorica & 28.1384 & -17.2269 & 1 & $\mathrm{H} 3$ & FJ408987 & FJ408898 \\
\hline 6 & Spain & Cedro, La Gomera (Canary I.) & L. azorica & 28.1500 & -17.2001 & 1 & H3 & FJ408988 & FJ408899 \\
\hline 7 & Spain & Cuevas Negras, Tenerife (Canary I.) & L. azorica & 28.3370 & -16.8090 & 1 & $\mathrm{H} 3$ & FJ409036 & FJ408947 \\
\hline 8 & Spain & Taganana, Tenerife (Canary I.) & L. azorica & 28.5513 & -16.2053 & 1 & H3 & FJ409032 & FJ408943 \\
\hline 9 & Spain & Los Tilos, Gran Canaria (Canary I.) & L. azorica & 28.0892 & -15.5933 & 1 & $\mathrm{H} 3$ & FJ408986 & FJ408897 \\
\hline 10 & Morocco & Anezi, Tiznit (Anti-Atlas) & L. azorica & 29.6600 & -9.3600 & 1 & $\mathrm{H} 3$ & FJ409040 & FJ408951 \\
\hline 11 & Morocco & Oumarhouz, Addar (Anti-Atlas) & L. azorica & 29.7500 & -9.2550 & 1 & $\mathrm{H} 3$ & FJ409007 & FJ408918 \\
\hline 12 & Morocco & Jb. Tazerkount (Middle Atlas) & L. azorica & 32.1667 & -6.4667 & 1 & $\mathrm{H} 3$ & FJ409034 & FJ408945 \\
\hline
\end{tabular}




\begin{tabular}{|c|c|c|c|c|c|c|c|c|c|}
\hline 13 & Morocco & Jb. Tazemit (Middle Atlas) & L. azorica & 32.3000 & -6.2667 & 1 & $\mathrm{H} 3$ & FJ409033 & FJ408944 \\
\hline 14 & Morocco & Jb. Ksiba (Middle Atlas) & L. azorica & 32.5000 & -6.0000 & 1 & $\mathrm{H} 3$ & FJ408998 & FJ408909 \\
\hline 15 & Morocco & $\mathrm{Jb}$. Bouhachem (Rif) & L. nobilis & 35.2333 & -5.4500 & 3 & H6 & FJ408967/68/69 & FJ408878/79/80 \\
\hline 16 & Spain & Río Miel, Algeciras (Cádiz) & L. nobilis & 36.1110 & -5.5035 & 2 & H5 & FJ409004/05 & FJ408915/16 \\
\hline 17 & Spain & Llanos del Juncal (Cádiz) & L. nobilis & 36.1078 & -5.5344 & 3 & H5 & FJ408999/9000/9001 & FJ408910/11/12 \\
\hline 18 & Spain & Tiradero (Cádiz) & L. nobilis & 36.1725 & -5.5978 & 3 & H5 & FJ409037/38/39 & FJ408948/49/50 \\
\hline 19 & Spain & Cruz del Romero (Cádiz) & L. nobilis & 36.1756 & -5.6083 & 3 & H5 & FJ408979/80/81 & FJ408890/91/92 \\
\hline 20 & Spain & Gta. Hoya (Cádiz) & L. nobilis & 36.205 & -5.6325 & 2 & H5 & FJ408989/90 & FJ408900/01 \\
\hline 21 & Spain & Aljibe (Cádiz) & L. nobilis & 36.5300 & -5.6300 & 2 & H6 & FJ408958/59 & FJ408869/70 \\
\hline 22 & Spain & Pasadallana (Cádiz) & L. nobilis & 36.5186 & -5.5983 & 3 & H5 & FJ409024/25/26 & FJ408935/36/37 \\
\hline 23 & Spain & La Jarda (Cádiz) & L. nobilis & 36.5678 & -5.5903 & 3 & H5 & FJ408995/96/97 & FJ408906/07/08 \\
\hline 24 & Spain & Gta. Verde (Cádiz) & L. nobilis & 36.8143 & -5.40475 & 3 & H5 & FJ408991/92/93 & FJ408902/03/04 \\
\hline 25 & Portugal & Sintra (Lisbon) & L. nobilis & 38.7821 & -9.4225 & 1 & H6 & FJ409027 & FJ408938 \\
\hline 26 & Spain & Carballo (Galicia) & L. nobilis & 43.2172 & -8.7822 & 1 & H6 & FJ408984 & FJ408895 \\
\hline 27 & Spain & Cortegada (Galicia) & L. nobilis & 42.6167 & -8.7667 & 1 & H6 & FJ408975 & FJ408886 \\
\hline 28 & Spain & Pontedeume (Galicia) & L. nobilis & 43.4153 & -8.1026 & 1 & H6 & FJ408985 & FJ408896 \\
\hline 29 & Spain & Sta. $\mathrm{M}^{\mathrm{a}}$ del Naranco (Asturias) & L. nobilis & 43.3881 & -5.8680 & 1 & H6 & FJ409010 & FJ408921 \\
\hline 30 & Spain & Monte Ulía (Basque Country) & L. nobilis & 43.3328 & -1.9525 & 1 & H6 & FJ409009 & FJ408920 \\
\hline
\end{tabular}




\begin{tabular}{|c|c|c|c|c|c|c|c|c|c|}
\hline 31 & Spain & Montnegre (Catalonia) & L. nobilis & 41.9500 & 2.9333 & 1 & H6 & FJ409006 & FJ408917 \\
\hline 32 & Spain & Montserrat (Catalonia) & L. nobilis & 41.613 & 1.799 & 1 & H6 & FJ409031 & FJ408942 \\
\hline 33 & France & Béziers (Languedoc) & L. nobilis & 43.4547 & 2.9347 & 1 & H6 & FJ408966 & FJ408877 \\
\hline 34 & France & Caux (Languedoc) & L. nobilis & 43.4944 & 3.3503 & 1 & H6 & FJ408982 & FJ408893 \\
\hline 35 & France & Pommiers (Languedoc) & L. nobilis & 43.9575 & 3.6122 & 1 & H6 & FJ408983 & FJ408894 \\
\hline 36 & Spain & Tramuntana, Mallorca (Balearic Islands) & L. nobilis & 39.8245 & 2.8288 & 1 & H6 & FJ409003 & FJ408914 \\
\hline 37 & Algeria & Algiers & L. nobilis & 36.4000 & 2.8500 & 1 & H6 & FJ408963 & FJ408874 \\
\hline 38 & Italy & Villanova Monteleone (Sardinia) & L. nobilis & 40.5045 & 8.5000 & 1 & H6 & FJ408974 & FJ408885 \\
\hline 39 & Italy & Santulussurgiu (Sardinia) & L. nobilis & 40.1300 & 8.6458 & 1 & H6 & FJ408973 & FJ408884 \\
\hline 40 & Italy & Rovolon, Padua & L. nobilis & 45.3666 & 11.6670 & 1 & H6 & FJ409011 & FJ408922 \\
\hline 41 & Italy & Monti dell'Uccellina (Toscana) & L. nobilis & 42.6333 & 11.0836 & 1 & H6 & FJ409041 & FJ408952 \\
\hline 42 & Italy & Fiora River (Viterbo) & L. nobilis & 42.4165 & 11.6350 & 1 & H6 & FJ409043 & FJ408954 \\
\hline 43 & Italy & Marangone Valley (Lazio) & L. nobilis & 42.0500 & 11.8170 & 1 & H6 & FJ409020 & FJ408931 \\
\hline 44 & Italy & Bari (Puglia) & L. nobilis & 41.0300 & 16.4900 & 1 & H6 & FJ409018 & FJ408929 \\
\hline 45 & Croatia & Sibenik & L. nobilis & 43.7409 & 15.8943 & 1 & H6 & FJ487607 & FJ487609 \\
\hline 46 & Croatia & Split & L. nobilis & 43.5066 & 16.4421 & 1 & H6 & FJ487608 & FJ487610 \\
\hline 47 & Greece & Sami (Kefalonia) & L. nobilis & 38.2531 & 20.6606 & 3 & $\mathrm{H} 1$ & FJ409021/22/23 & FJ408932/33/34 \\
\hline 48 & Greece & Poros (Kefalonia) & L. nobilis & 38.1489 & 20.7929 & 3 & $\mathrm{H} 1$ & FJ409015/16/17 & FJ408926/27/28 \\
\hline
\end{tabular}




\begin{tabular}{|c|c|c|c|c|c|c|c|c|c|}
\hline 49 & Greece & Mainalo (Peloponnese) & L. nobilis & 37.6666 & 22.2501 & 3 & H6 & FJ409012/13/14 & FJ408923/24/25 \\
\hline 50 & Greece & Crete & L. nobilis & 35.3469 & 23.7376 & 3 & H6 & FJ408976/77/78 & FJ408887/88/89 \\
\hline 51 & Greece & Athens & L. nobilis & 37.9802 & 23.7398 & 1 & H6 & FJ408964 & FJ408875 \\
\hline 52 & Greece & Andros (Cyclades) & L. nobilis & 37.8455 & 24.8817 & 3 & $\mathrm{H} 1$ & FJ408960/61/62 & FJ408871/72/73 \\
\hline 53 & Greece & Rhodes (Dodecanese) & L. nobilis & 36.3215 & 28.1544 & 1 & $\mathrm{H} 2$ & FJ409019 & FJ408930 \\
\hline 54 & Turkey & Sögutköy (Marmaris Peninsula) & L. nobilis & 36.6380 & 28.1892 & 3 & $\mathrm{H} 2$ & FJ409028/29/30 & FJ408939/40/41 \\
\hline 55 & Turkey & Bayirköy (Marmaris Peninsula) & L. nobilis & 36.7046 & 28.2233 & 3 & $\mathrm{H} 1, \mathrm{H} 2$ & FJ408970/71/72 & FJ408881/82/83 \\
\hline 56 & Israel & Mt. Carmel & L. nobilis & 32.6771 & 35.3019 & 1 & $\mathrm{H} 2$ & FJ409008 & FJ408919 \\
\hline 57 & Turkey & Akçaabat (Trabzon) & L. nobilis & 40.6836 & 40.7538 & 1 & $\mathrm{H} 2$ & FJ409042 & FJ408953 \\
\hline
\end{tabular}

* Western longitudes are negative 
Appendix S2 Plastid DNA regions sampled and primers used for the study of sequence variability in Laurus.

\begin{tabular}{|c|c|c|c|c|c|}
\hline Plastid region & Forward primer & Forward primer sequence & Reverse primer & Reverse primer sequence & References \\
\hline $\operatorname{trnH}$-trnK & trnH_GUG & ACG GGA ATT GAA CCC GCG CA & trnK_UUUr & CCG ACT AGT TCC GGG TTC GA & $\begin{array}{l}\text { Demesure et al. } \\
\text { (1995) }\end{array}$ \\
\hline$p s b C-t r n S$ & $\mathrm{psbC}$ & GGT CGT GAC CAA GAA ACC AC & trnS_UGAr & GGT TCG AAT CCC TCT CTC TC & $\begin{array}{l}\text { Demesure et al. } \\
\quad(1995)\end{array}$ \\
\hline 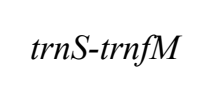 & trnS_UGA & GAG AGA GAG GGA TTC GAA CC & trnfM_CAUr & CAT AAC CTT GAG GTC ACG GG & $\begin{array}{l}\text { Demesure et al. } \\
\quad(1995)\end{array}$ \\
\hline $\operatorname{trn} Q-\operatorname{trn} R$ & $\operatorname{trnQf}$ & GGG ACG GAA GGA TTC GAA CC & $\operatorname{trnRr}$ & ATT GCG TCC AAT AGG ATT TGA A & $\begin{array}{l}\text { Dumolin-Lapegue } \\
\quad \text { et al. (1997) }\end{array}$ \\
\hline trnK-matK & $3914 \mathrm{~F}$ & TGG GTT GCT AAC TCA ATG G & $1470 \mathrm{R}$ & AAG ATG TTG AT(CT) GTA AAT GA & $\begin{array}{c}\text { Johnson \& Soltis } \\
\text { (1994) }\end{array}$ \\
\hline $\operatorname{trn} D-\operatorname{trn} T$ & trnD_GUC & ACC AAT TGA ACT ACA ATC CC & trnT_GGUr & CTA CCA CTG AGT TAA AAG GG & $\begin{array}{l}\text { Demesure et al. } \\
\text { (1995) }\end{array}$ \\
\hline $\operatorname{trnK}$-trnK & trnK_UUU & GGG TTG CCC GGG ACT CGA AC & trnK_UUUr2 & CAA CGG TAG AGT ACT CGG CTT TTA & $\begin{array}{l}\text { Demesure et al. } \\
\text { (1995) }\end{array}$ \\
\hline $\operatorname{trn} T-\operatorname{trn} L$ & TRN A & CAT TAC AAA TGC GAT GCT CT & TRN B & TCT ACC GAT TTC GCC ATA TC & $\begin{array}{l}\text { Taberlet } \text { et al. } \\
\text { (1991) }\end{array}$ \\
\hline $\operatorname{trn} M-r b c L$ & trnM_CAU & TGC TTT CAT ACG GCG GGA GT & rbcl_r & GCT TTA GTC TCT GTT TGT G & $\begin{array}{l}\text { Demesure et al. } \\
\text { (1995) }\end{array}$ \\
\hline psaA-trnS & psaA & ACT TCT GGT TCC GGC GAA CGA A & trnS_GGAr & AAC CAC TCG GCC ATC TCT CCT A & $\begin{array}{l}\text { Demesure et al. } \\
\text { (1995) }\end{array}$ \\
\hline $\operatorname{trn} C$-trnD & trnC_GCA & CCA GTT CAA ATC TGG GTG TC & trnD_GUCr & GGG ATT GTA GTT CAA TTG GT & $\begin{array}{l}\text { Demesure et al. } \\
\text { (1995) }\end{array}$ \\
\hline
\end{tabular}

\section{REFERENCES}


Demesure, B., Sodzi, N. \& Petit, R. J. (1995) A set of universal primers for amplification of polymorphic non-coding regions of mitochondrial and chloroplast DNA in plants. Molecular Ecology, 4, 129-131.

Dumolin-Lapegue, S., Pemonge, M.-H. \& Petit, R.J. (1997) An enlarged set of consensus primers for the study of organelle DNA in plants. Molecular Ecology, 6, 393-397.

Johnson, L.A. \& Soltis, D.E. (1994) matK DNA sequences and phylogenetic reconstruction in Saxifragaceae s. str. Systematic Botany, 19(1), 143-156.

Taberlet, P., Gielly, L., Pautou, G. \& Bouvet, J. (1991) Universal primers for amplification of three non-coding regions of chloroplast DNA. Plant Molecular Biology, 17, 1105-1109.

Tate, J. A. \& Simpson, B. B. (2003) Paraphyly of Tarasa (Malvaceae) and diverse origins of the polyploid species. Systematic Botany, 28, 723737. 
Appendix S3 Map of Laurus fossil records for the Neogene and source references. Square symbols represent uncertain records (classified as Laurophyllum).

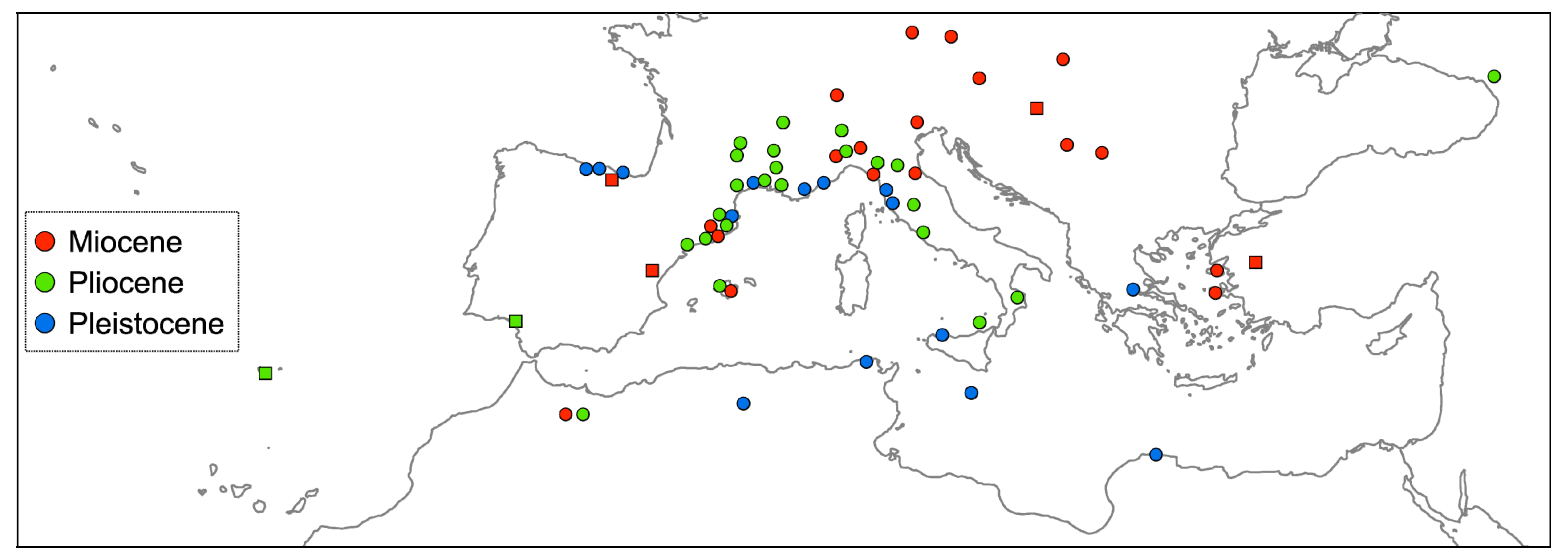

\section{REFERENCES}

Akgün, F., Kayseri, M.S. \& Akkiraz, M.S. (2007) Palaeoclimatic evolution and vegetational changes during the late Oligocene-Miocene period in Western and Central Anatolia (Turkey). Palaeogeography, Palaeoclimatology, Palaeoecology, 253, 56-90.

Axelrod, D. I. (1975) Evolution and biogeography of Madrean-Tethyan sclerophyll vegetation. Annals of the Missouri Botanical Garden, 62, 280-334.

Barbero, M., Benabid, A., Peyre, C., \& Quézel, P. (1981) Sur la presence au Maroc de Laurus azorica (Seub.) Franco. Anales del Jardín Botánico de Madrid, 37, 467-472.

Barrón, E. (1995) Estudio tafonómico y análisis paleoecológico de la macro y microflora miocena de la cuenca de la Cerdaña. Universidad Complutense de Madrid, Spain.

Barrón, E. \& Peyrot, D. (2006) La vegetación forestal en el Terciario. Paleoambientes y cambio climático (ed. by J. S. Carrión, S. Fernández and N. Fuentes), pp. 55-76. Fundación Séneca - Agencia de Ciencia y Tecnología de la Región de Murcia, Murcia, Spain. 
Bollinger, T. H. (1992) Kleinsäugerstratigraphie in der miozänen Hörnlischüttung (Ostschweiz). Documenta Naturae, 75, 1-296.

Bottema, S. (1979) Pollen analytical investigations in Thessaly (Greece). Palaeohistoria, 21,19-40.

Buechler, W. (2003) Oligocene macroflora of Ebnat-Kappel (Switzerland). Pangaea, doi:10.1594/PANGAEA.106219.

Butzer, K. W. (1958) The near East during the last glaciation: a palaeogeographical sketch. The Geographical Journal, 124, 367-369.

Erdei, B., Hably, L., Kázmér, M., Utescher, T. \& Bruch, A.A. (2007) Neogene flora and vegetation development of the Pannonian domain in relation to palaeoclimate and palaeogeography. Palaeogeography, Palaeoclimatology, Palaeoecology, 253, 115-140.

Ferguson, D. K. (1974) On the taxonomy of recent and fossil species of Laurus (Lauraceae). Botanical Journal of the Linnean Society, 68, 51-72.

Giacobbe, A. (1939) Richerche geografiche et ecologiche sul Laurus nobilis L. Archivio Botanico, 15, 33-82.

Hably, L. (2003) Oligocene/Miocene macroflora of Andornaktalya (Hungary). Pangaea, doi:10.1594/PANGAEA.98752.

Heer, O. (1857) Über die fossilen pflanzen von St. Jorge in Madeira. Neue Denkschriften der Allgemeinen schweizerischen Gesellschaft für die gessamten Naturwissenschaften, 5.

Kovar-Eder, J., Kvaček, Z., \& Meller, B. (2001) Comparing Early to Middle Miocene floras and probable vegetation types of Oberdorf $\mathrm{N}$ Voitsberg (Austria), Bohemia (Czech Republic), and Wackersdorf (Germany). Review of Palaeobotany and Palynology, 114, 83-125. 
Kvaček, Z. \& Teodoridis, V. (2007) Tertiary macrofloras of the Bohemian Massif: a review with correlations within Boreal and Central Europe. Bulletin of Geosciences, 82, 383408 .

Lozano, P., Meaza, G., \& Cadiñanos, J. A. (2002) Paleobiogeografía cultural de la reserva de la biosfera de Urdaibai (Vizcaya). Boletín de la A. G. E., 34, 193-211.

Lumley, H. (1988) La grotte du Vallonnet, Roquebrune-Cap-Martin, Alpes-Maritimes. Situation géographique, description, historique. L'Anthropologie, 92, 387-398.

Martinetto, E., Uhl, D., \& Tarabra, E. (2007) Leaf physiognomic indications for a moist warm-temperate climate in NW Italy during the Messinian (Late Miocene). Palaeogeography, Palaeoclimatology, Palaeoecology, 253, 41-55.

Quézel, P. (1978) Analysis of the flora of Mediterranean and Saharan Africa. Annals of the Missouri Botanical Garden, 65, 479-534.

Sanz de Siria, A. (1994) La evolución de las paleofloras en las cuencas cenozoicas catalanas. Acta Geológica Hispánica, 29, 169-190.

Teodoridis, V. \& Kvaček, Z. (2006) Palaeobotanical research of the Early Miocene deposits overlying the main coal seam (Libkovice and Lom Members) in the Most Basin (Czech Republic). Bulletin of Geosciences, 81, 93-113.

Utescher, T., Djordjevic-Milutinovic, D., Bruch, A., \& Mosbrugger, V. (2007) Palaeoclimate and vegetation change in Serbia during the last 30 Ma. Palaeogeography, Palaeoclimatology, Palaeoecology, 253, 141-152.

Uzquiano, P. (2005) El registro antracológico durante la transición Musteriense-Paleolítico Superior Inicial en la región cantábrica: vegetación, paleoambiente y modos de vida alrededor del fuego. Monografías del Museo de Altamira, 20, 255-274.

Velitzelos, E. \& Gregor, H.-J. (1990) Some aspects of the Neogene floral history in Greece. Review of Palaeobotany and Palynology, 62, 291-307. 
Vicens, M. M. (1996) A Botanic Garden of the Mediterranean Islands. BGCNews, 2 (6). 